\title{
RESEARCH AND CONSERVATION IN THE ROMAN BATHS OF MARINA EL-ALAMEIN IN THE 2012 AND 2013 SEASONS (POLISH- EGYPTIAN CONSERVATION MISSION)
}

\author{
Rafał Czerner,' Grażyna Bąkowska-Czerner, 'rzegorz Majcherek ${ }^{3}$ \\ ${ }^{1}$ Wrocław University of Technology, ${ }^{2}$ Jagiellonian University, \\ ${ }^{3}$ Polish Centre of Mediterranean Archaeology, University of Warsaw
}

\begin{abstract}
A Roman bath in use from the 2nd to the 4th century AD at the harbor of Marina el-Alamein on the Mediterranean coast of Egypt continued to be researched, conserved and prepared for exhibition by the Polish-Egyptian Conservation Mission working under the auspices of the Polish Centre of Mediterranean Archaeology, University of Warsaw and the Faculty of Architecture, Wrocław University of Technology. The bath and adjacent civic basilica were located in the center of the ancient town, to the south of the ruins of the main square. By updating results of research carried out in previous seasons, the present studies on the caldarium and frigidarium of the bath and a part of the civic basilica have brought us significantly closer to identifying the functional layout of the southern baths. Phases of construction were investigated as well and it is now possible to trace the transformation of the building over time.
\end{abstract}

Keywords: Marina el-Alamein, Roman baths, civic basilica, architecture, research, preservation, conservation

Research, conservation and site presentation priorities of the Polish-Egyptian Conservation Mission, working in Marina el-Alamein in Egypt under the auspices of the Polish Centre of Mediterranean Archaeology, University of Warsaw and the Faculty of Architecture, Wrocław University of Technology, were focused on the area south of the central square of the ancient harbor town. A Roman bath was located there, directly to the south of the main square [Fig. 1] and connected with a civic basilica to the east. The complex was in use from the 2 nd to the 4 th century AD.

The northern part of this complex was uncovered by an archaeological mission headed by Wiktor A. Daszewski from the Polish Centre of Mediterranean Archaeology shortly after the discovery of the site in 1985 (Daszewski 1995: 19-20). The excavation of the basilica was resumed in 2005 (Daszewski 2007: 79-82). In 2006 and 2007, Egyptian archaeologists contracted by an ARCE/EAP Site Pre- 
Rafał Czerner, Grażyna Bąkowska-Czerner, Grzegorz Majcherek

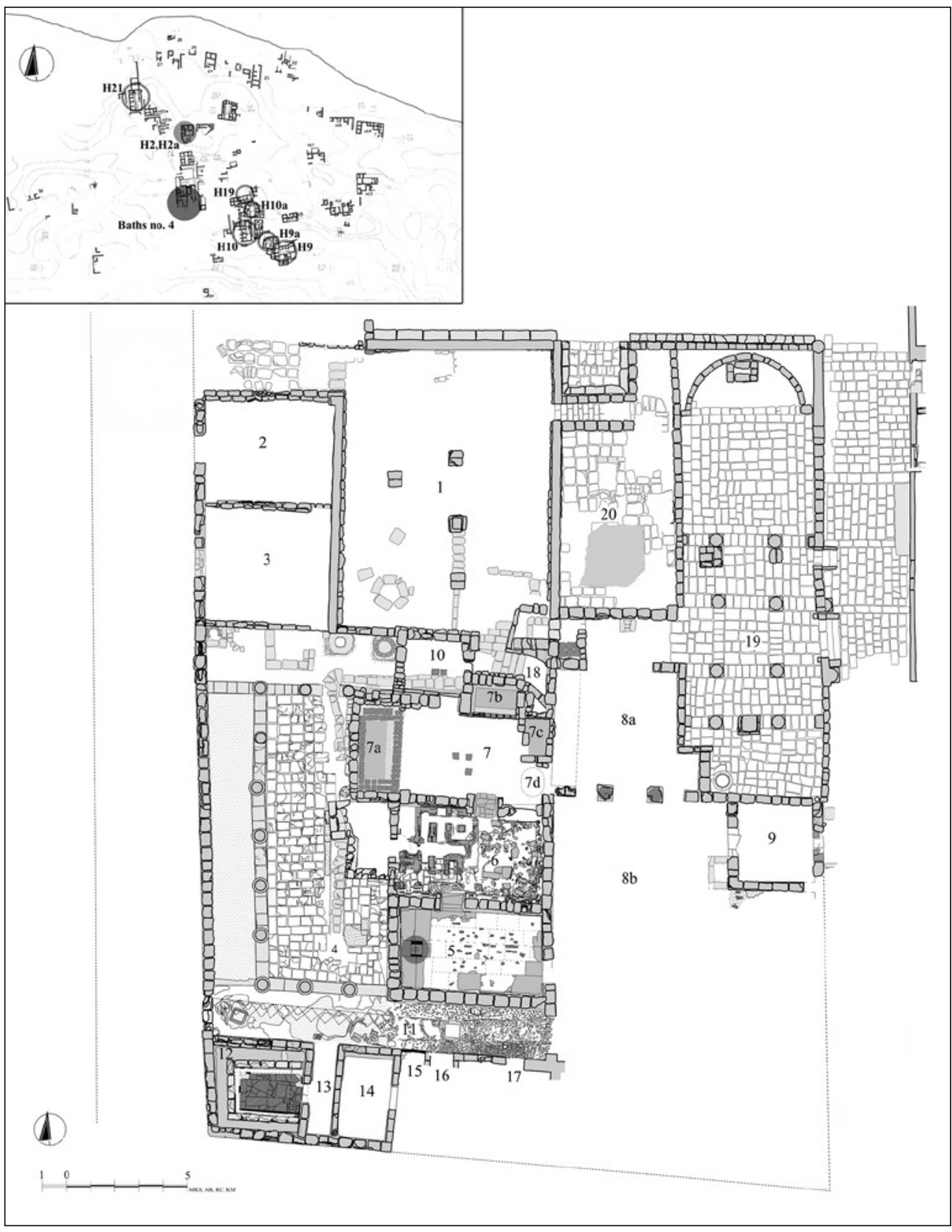

Fig. 1. Plan of the baths and the civic basilica located south of the central square at Marina el-Alamein; inset, location of the bath complex on the city plan (Drawing A. Btaszczyk, A. Brzozowska, R. Czerner, M. Krawczyk-Szczerbinska, K. Majdzik) 
sentation project excavated the part of the complex situated further to the south, partly clearing rooms marked as Nos 4, 5, 6 and 7 on the plan. The Polish-Egyptian Conservation Mission began work in 2008 and extended the undertaking in 2009-2012 (Medeksza et al. 2011: 116-118; Medeksza, Czerner, and Bąkowska-Czerner 2012: 84-99).

A portico courtyard (No. 4) was cleared in the western part of the bath; the walls were protected and an anastylosis of several columns was carried out. Relics of a heating system in room 6 and in the neighboring room 7 started to be conserved as well. Additional rooms: 5 and partly 8 , were also cleared to begin research and conservation. In the 2012 and 2013 seasons, the range of conservation and research was expanded to include further rooms.

In 2012, the mission carried out a thorough conservation and filled in the structure and stonework on the surface of the most damaged walls in room 7 . The relics of alvei located there also underwent conservation. Proper site presentation was prepared. Work continued on rooms $8 \mathrm{a}$ and $8 \mathrm{~b}$, first of all by protecting the walls and constructing on top of their remains. Two marble bases and a fragment of column shaft were set up on plinths surviving in the passage between the two interiors. Room 11, which was a wide corridor constituting an extension of the southern portico of courtyard 4 to the east, was cleared. Fragments of its south wall were filled in. A number of the small rooms and corridors located south of rooms 4 and 11 started to be cleared as well.

The southwestern part of the bath continued to be uncovered in 2013 . The most westward room situated there (No. 12), housing a latrine, was fully examined and the neighboring rooms 13 and 14 were partly examined. Conservation of this section of the complex began. Under the floor of the western part of room $8 \mathrm{a}$, a partly collapsed cryptoportico and stairs leading to it (No. 18) were uncovered. Additionally, the structure of the cryptoportico was discovered, and its west wall was partly reconstructed. In the eastern part of the bath, room 9 neighboring on the civic basilica was examined and its walls were partly reconstructed. Also the southern part of the basilica (No. 19) was examined and cleared.

By updating results of research carried out in previous seasons, particularly in 2009 and 2011, the present studies have brought us significantly closer to identifying the functional layout of the southern baths. Phases of construction were investigated as well and it is now possible to trace the transformation of the building over time.

\section{FUNCTIONAL LAYOUT OF THE BATHS}

The small baths with their asymmetrical layout, occupying an insula in a densely built-up urban area, are typical balnea (Nielsen 1990: 3) [Fig. 1]. The layout of the rooms serving the main functions indicate that it was a row-type bath (Krencker et al. 1929: Figs 234240; Nielsen 1990: 87).

The results of this year's study have added new detail to the findings of earlier seasons without changing the broad outlines of the reconstruction of 
the layout of the southern bath complex and of the way in which it functioned. Water reservoirs were situated to the north, on an elevated base. The vast room 1 west of the tanks was a utility courtyard. From there, stairs (No. 18) led down to a cryptoportico (where a praefurnium was located) running along the east foundation wall of room 7 , under the floor of room $8 \mathrm{a}$. The praefurnium provided heat for room 7 . But the results of recent research have indicated that the praefurnium was originally located elsewhere. Rooms 7, 6, 5, including a spacious hall completing the complex to the east (formed of the two joined interiors 8 and $8 \mathrm{a}$ ), created a functional sequence of caldarium, pro-bably two tepidaria (or sudatorium and tepidarium) and frigidarium. One of the main entrances to the bath led from the street, from the west to the southern portico of the courtyard (No. 4). It then led into corridor 11 leading to hall 8 . The second entrance to this hall, providing access to the bath, led from the east, from the neighboring civic basilica, through a vestibule opening into hall $8 \mathrm{a}$ to the north. Another entrance to hall 8 led from the street, from the east through the small vestibule 9, adjacent to the basilica from the south. South of courtyard 4 and corridor 11, the complex of small rooms 12-17 was situated. The unit marked 12 turned out (in the course of research in
2012 and continued in 2013) to be a very elegant latrine. A passage (No. 13) led to it. Further interiors were probably similar in function.

Investigation of caldarium 7 , carried out intensively in 2012, showed it to have been transformed considerably and extended to the west. It used to be smaller with its west wall in line with the walls of the neighboring rooms 6 and 5. It means that the neighboring courtyard 4 was originally regular and its east side was closed with a wall lined up with the wall of the three said rooms. The northern portico had three spans, just like the southern one on the opposite side.

In the next construction phase, room 7 was extended to the west, taking over part of the peristyle courtyard. A new bath (No. 7a) was situated in the added space. Room 6, the hypocaustum of which used to be heated indirectly, was equipped at this time with its own praefurnium. The furnace was situated to the west of it, and accessible down stairs from the courtyard. Both of these changes considerably disturbed the stately nature of the courtyard. Also the northern and eastern parts of caldarium 7 were altered while changing the layout of the heating system. The elements of the transformation as listed above were fairly extensive. The alteration may have been connected with a rebuilding event that followed crucial damages of some kind.

\section{ARCHITECTURAL DESCRIPTION}

Room 4 (investigated by the team concurrently with conservation and building work in the 2009 and 2011 seasons) was a rectangular courtyard with porticoes on the northern, western and southern sides. A floor mosaic of large tesserae was discovered in the southern portico. This passage extended to the east into corridor 11 , which was $2.03 \mathrm{~m}$ wide and which led to hall $8 \mathrm{a}$. It was cleared in 2012. More of the mosaic floor was uncovered there [Fig. 2], indicating that 
the entire portico and corridor were finished thus.

Four entrances opened to the south from the southern portico of courtyard 4 and from corridor 11 . The western one, situated on the axis of the central intercolumnation of the portico, leads to the corridor running to the south and providing access to the relatively small room 12 . It was $3.86 \mathrm{~m}$ long to the north, narrowing to $3.31 \mathrm{~m}$ at the southern end. From north to south, it was $3.49-3.51 \mathrm{~m}$ wide. Excavation revealed a latrine [Fig. 3] with a grey marble floor made of slabs of different size. Marble slabs revetted the lower part of the east wall of the room, up to a height of about $0.30 \mathrm{~m}$ on either side of the entrance. Above this facing and above the seats on the other sides, the walls were plastered and painted with polychrome motifs; fragments of this decoration were discovered. The seats rested on long wooden beams, the ends of which were fixed into sockets in the wall.

A channel ran along the east, north and south walls. A small duct, about $0.20 \mathrm{~m}$ wide and $0.08-0.10 \mathrm{~m}$ high, lined the low wall surrounding the latrine drain, on the level of the floor. It was faced with long marble slabs. On the fourth side the drain was connected with another drain hidden under the flooring, under the entrance to the room. Water to flush the drain was probably supplied through an opening in the north wall next to the northeastern corner. It was removed through another opening in the north

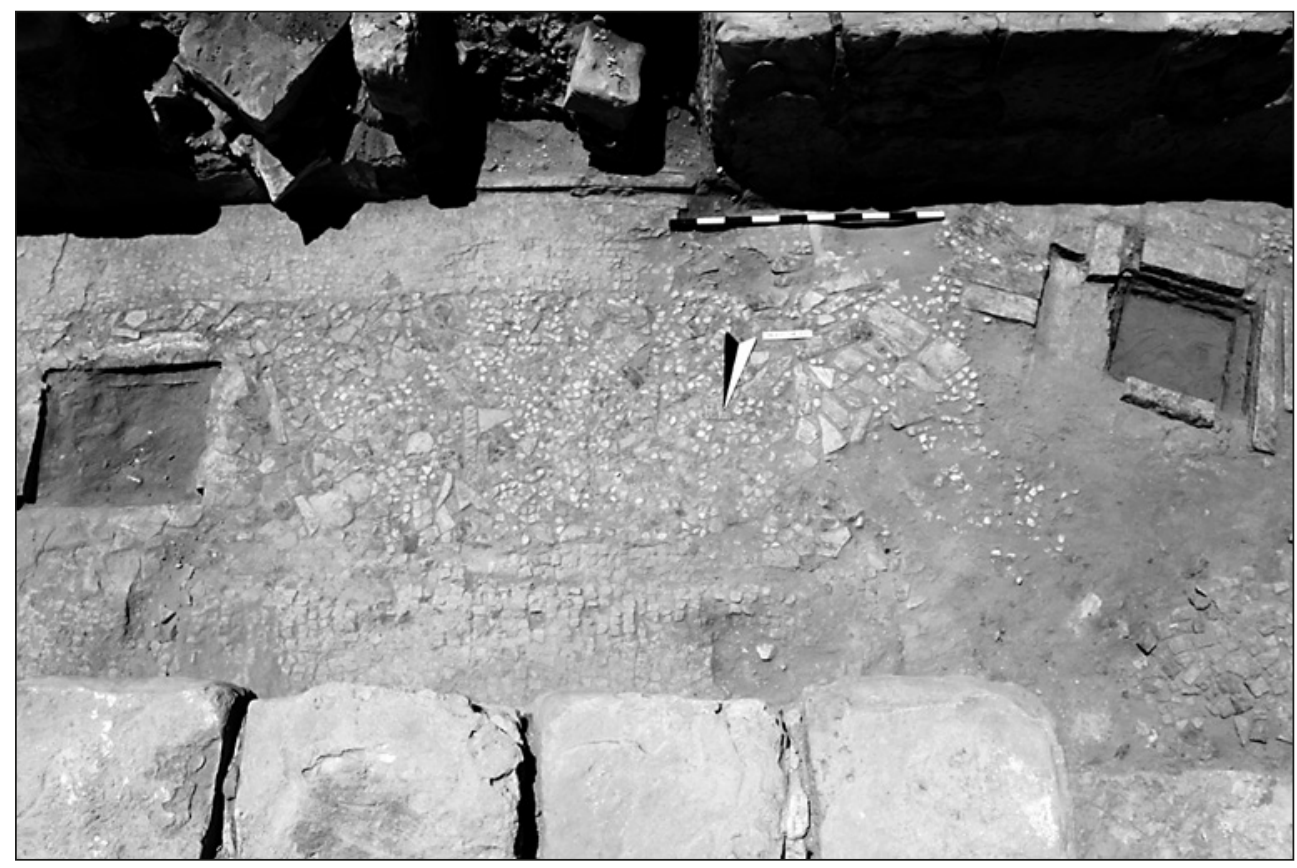

Fig. 2. Southern baths, mosaic in corridor 11 (Photo R. Czerner) 
wall, spewing into a sewage pit situated under the western part of the southern portico of courtyard 4.

Corridor 13, which was situated east of the latrine, was $0.82 \mathrm{~m}$ wide. An entrance from it led sideways into this room. The walls of the corridor were covered with polychrome plaster. The next room (No. 14) was 2.15-2.20 m wide and $3.53 \mathrm{~m}$ long. The walls were covered with several layers of waterproof mortar. Two entrances further to the east led to two parallel corridors 15 and 16 , which were $1.00 \mathrm{~m}$ and $0.95 \mathrm{~m}$ wide respectively. Further to the east, in room 17, to which the last entrance led from the north, research has just started. All that can be said is that it was $3.78 \mathrm{~m}$ wide.
The hall which was identified as the caldarium, room 7 , was the northernmost of three rooms immediately adjacent to the portico courtyard 4 on the east and investigated in 2009 [Fig. 4]. It was longer than the other two and stretched further to the west into the space of the courtyard. This was the effect of expansion in a later phase as described above. The plan was close to a rectangle with inner measurements of approximately 7.81$7.90 \mathrm{~m}$ by $3.34-3.43 \mathrm{~m}$, stretching from east to west, the north end distorted by the recess in which alveus $7 \mathrm{~b}$ is located. The hall was connected with room 6 through an entrance $0.90 \mathrm{~m}$ wide, situated in the south wall, $1.88 \mathrm{~m}$ from its eastern end. The south wall of the caldarium and

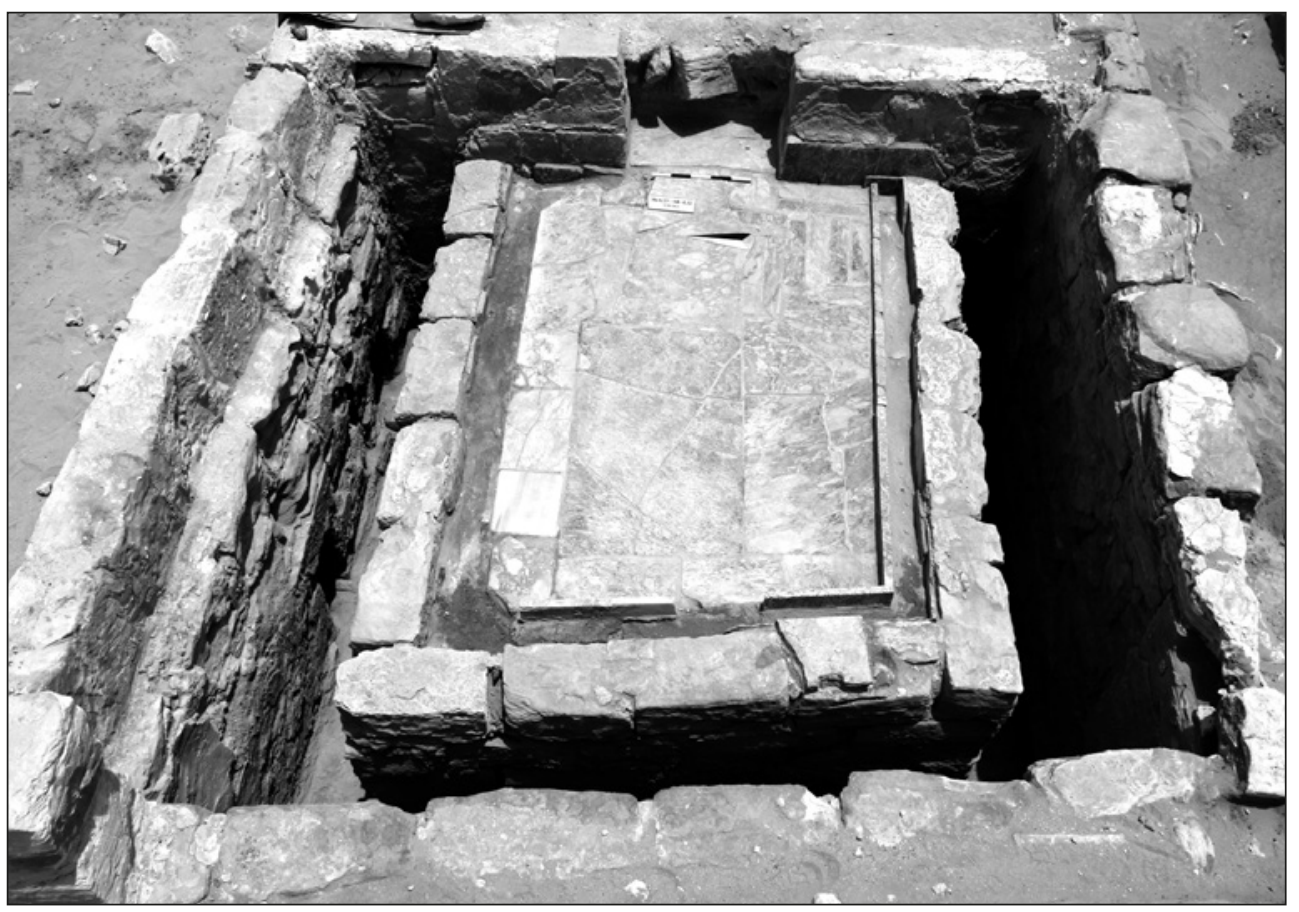

Fig. 3. Southern baths, latrine in room 12 after conservation in 2013 (Photo R. Czerner) 
Research and conservation in the Roman baths of Marina el-Alamein in the 2012 and 2013... EGYPT
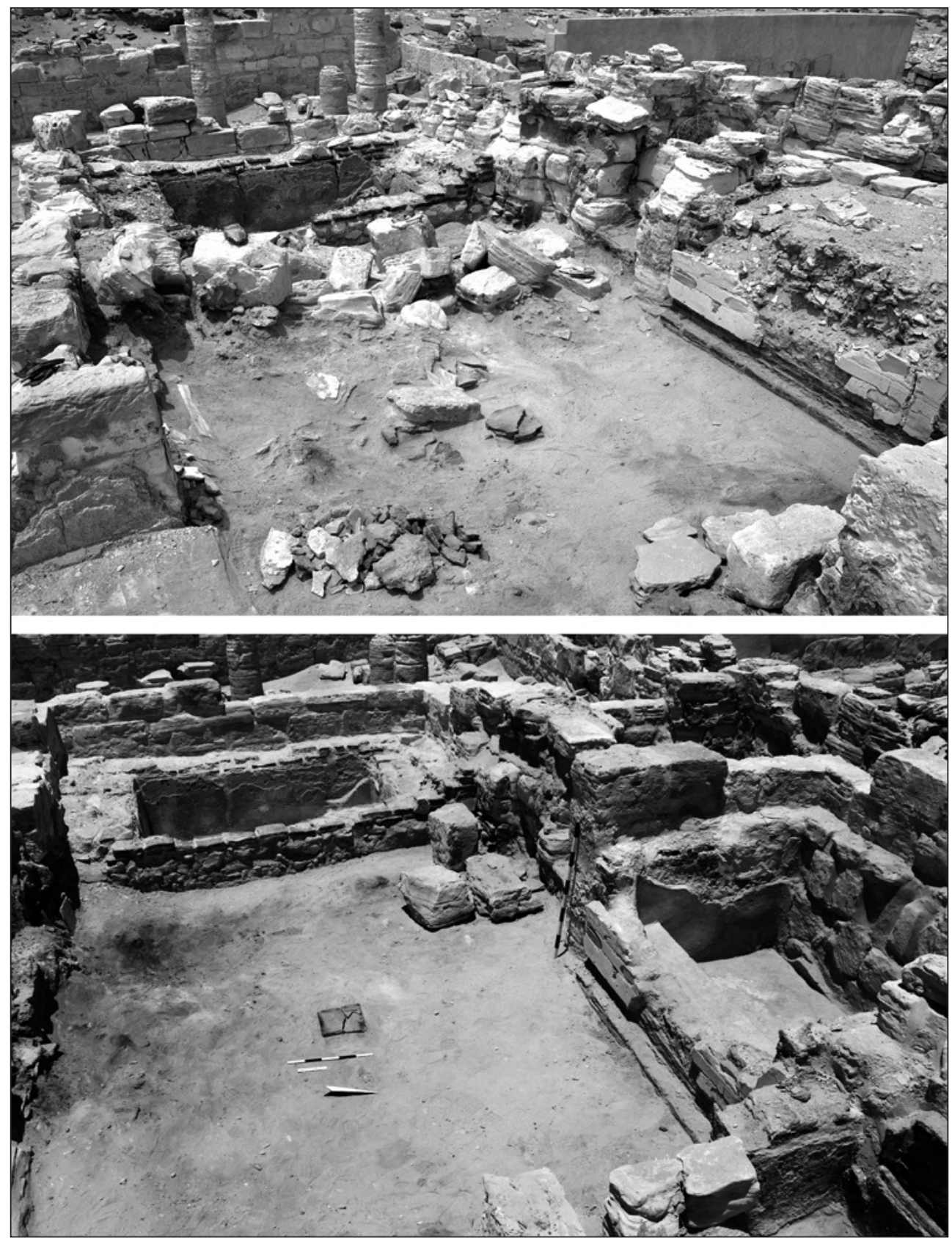

Fig. 4. Southern baths, caldarium in room 7 before (top) and after (bottom) conservation in 2012 (Photos R. Czerner) 
a considerable part of the north wall were built from typical, 0.43 -m-wide, limestone blocks with the other dimensions being $0.55-0.60 \mathrm{~m}$ by $0.26-0.28 \mathrm{~m}$. All the other walls, especially the west ones, were made of different blocks, most of them $0.35 \mathrm{~m}$ wide. A floor of ceramic tiles, which failed to survive except for a few relics, was supported on pilae, the tops of which can be seen sticking out from the rubble. Flues, made of ceramic tubuli or flat ceramic tiles, extended vertically in the south wall and partly in the northern one; their purpose was to remove smoke from the hypocaust.

To the west, the full width of the room was occupied by a basin, a bath (No. 7a), partly sunk below floor level, built of bricks and lined with several layers of waterproof plaster. Its inner dimensions were $1.00 \mathrm{~m}$ by $2.20 \mathrm{~m}$. It corresponded to two annexes (Nos $7 \mathrm{c}$ and $7 \mathrm{~d}$ ) in the eastern part of the complex. The former annex was separated from room 7 in a later phase. A fragment of the heating system, encompassing all the functional parts, has survived by the north wall of this annex. These were elements of the hypocaust: a pila and a fragment of ceramic floor tile, and flues in the wall.

Another bath, alveus 7b, not sunk and probably heated, with inner dimensions of $1.81-1.72 \mathrm{~m}$ by $0.90 \mathrm{~m}$, was located in the recess opening in the north wall of the caldarium, opposite the entrance. The walls of the recess projected to the north, out of the outer wall line. The two pools were built when the room was

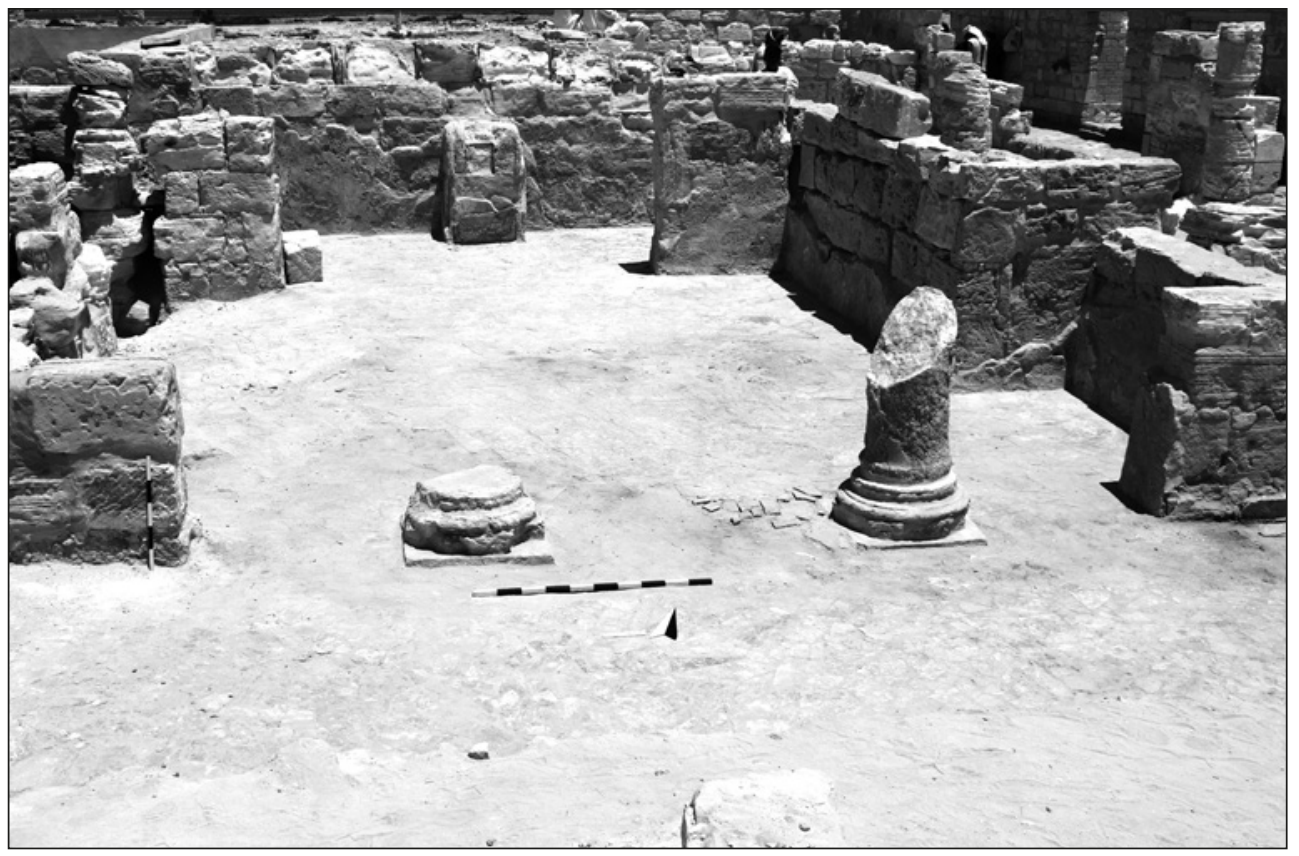

Fig. 5. Southern baths, rooms $8 a$ and 86 after conservation in 2012 (Photo R. Czerner) 
reconstructed. They shared a system for carrying water away through a channel running outside the room, along its north and west walls, to the south. However, the northern alveus could well have been built in place of a similar earlier one. Some of its walls originated from an earlier phase, while others were added to them. This earlier alveus may have been situated above a praefurnium, now lost, which had originally heated room 7 and also indirectly room 6 . This can be inferred from the location in the middle of wide stairs opening to the south from the utility courtyard 1 . It would have been logical for a praefurnium to be situated in this position and this was surely the case in the original phase. A complicated passage around the corner of the outer walls of room 7 , which has survived with stairs leading to the cryptoportico and praefurnium situated to the east, passing through two older walls and descending under the floor of adjoining room $8 \mathrm{a}$, might have been connected with some rebuilding.

Neighboring on the caldarium to the north was room 10 , situated to the west of the recess containing the later bath (No. 7b). The west wall of this chamber is lined up with the outer walls of rooms 5,6 , and a wall of room 7 before it was extended. In the original phase, room 10 was entered from the caldarium. After the alteration, the entrance was walled in and the room became completely inaccessible.

Hall 8, formed of the two joined interiors $(8 \mathrm{a}$ to the north and $8 \mathrm{~b}$ to the south), is the biggest of the rooms in the bath excavated so far [Fig. 5]. It ran $15.95 \mathrm{~m}$ from north to south. Its width increased with several recesses, beginning with $5.02 \mathrm{~m}$ to the north to over $10 \mathrm{~m}$ to the south. The hall was divided in the middle of its length by a wall with a wide passage $(4.45 \mathrm{~m})$ with columns standing on both sides. The foundations of the columns have survived. In the north wall of the hall there was a passage $2.93 \mathrm{~m}$ wide, opening into the next room from which, to the east, a basilica neighboring the baths was entered. By the north wall of the room, in the middle of it, there was a pedestal with a partly preserved marble slab bearing an inscription from the times of Hadrian (discovered by the achaeological mission in 2005, see Daszewski 2007: 75-90). The more spacious southern part of the hall was entered from the west, from corridor 11 leading from courtyard 4 , through a doorway next to the southwestern corner. The entrance was $1.53 \mathrm{~m}$ wide. Both parts of the hall were paved with a marble floor. The walls were plastered and polychromed.

A cryptoportico was built in room 8a, along its west wall. It ran under the floor, leading to the praefurnium that heated the hypocaust of room 7. The praefurnium was situated under the southeastern corner of room 7. Stairs 18 led from the west down to the northern part of the cryptoportico, through its west wall. For this purpose, an entry was made in the west wall of room $8 \mathrm{a}$, which was also the wall of the cryptoportico. There was no lintel over it, and the wall blocks above remained in place only because they had jammed. This indicates that this passage and the cryptoportico were made later. The original praefurnium must have been situated somewhere else.

The cryptoportico had a brick semibarrel vault with a quarter-circle crosssection. Its east side rested on its own 
foundation wall, and to the west it leaned against the wall between rooms 7 and $8 \mathrm{a}$. A small fragment of this vault has survived. The bricks in it were laid in an unusual manner, in a direction crosswise to the axis of the vault, and inclined towards the north, the outermost ones leaning against a shield wall. This clearly means that the vault was built without centring.

The walls of the southern part of the civic basilica demonstrate two building phases. The west wall, separating the basilica from room $8 \mathrm{a}$, together with a short

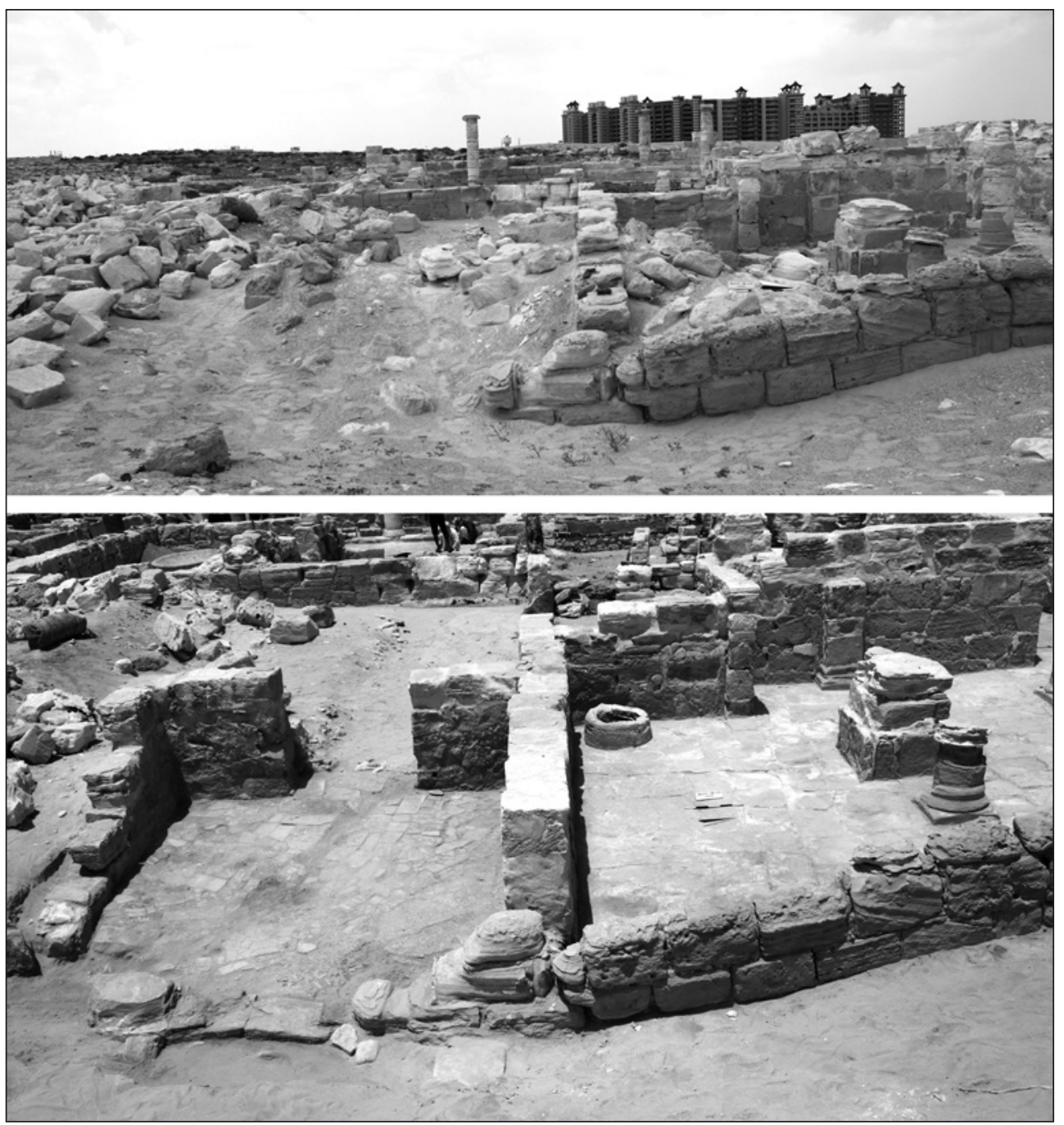

Fig. 6. Southern baths, room 9 and the southern part of the civic basilica, before (top) and after (bottom) conservation in 2013 (Photos R. Czerner) 
section of wall diverging from its southern end at a right angle to the east, is earlier. The south wall is similarly earlier. Originally, there was a passage left between the two walls. The walls may have belonged to the bath and the basilica was added to it. After clearing of the southern part of the basilica (room 19) and uncovering its flooring, it was found that there used to be a cistern under it. Water flowed from the roof and was channeled down a ceramic pipe in the southeastern corner of the room, while it was brought up through an encased opening in the southwestern corner. Cleaning of the adjacent room 9 to the south revealed a similar grey marble floor as in room 8 [Fig. 6].

\section{ARCHAEOLOGICAL RESEARCH}

Conservation work in the southern baths was preceded by clearing and test excavation done under archaeological supervision. The site had been excavated by the archaeological mission of Wiktor Andrzej Daszewski in 2005 (Daszewski 2007: 79-83) and by Egyptian archaeologists for the ARCE/EAP Site Presentation project working in Marina in the 2006 and 2007 seasons.

Room 7. Clearing of the chamber identified as a caldarium was completed in the 2012 season prior to the start of conservation and reconstruction [see Fig. 4]. An inventory plan was made first, following which the stone block tumble was removed from the interior. The dimensions of the room were $7.81 /$ $7.90 \mathrm{~m}$ by $3.43 / 3.34 \mathrm{~m}$; the walls, constructed of large stone blocks, rose to a height of $0.70-0.80 \mathrm{~m}$. The northern bath (No. 7b) and room 7c were cleared. For an assessment of the different building phases, see above, the architectural description. The caldarium had been rebuilt already in antiquity.

The chamber was connected with room 6 through a door that was $1.10 \mathrm{~m}$ wide in the south wall. In an earlier phase, the caldarium was connected also with room 10 , but the door, $0.76 \mathrm{~m}$ wide, was blocked later. A wall of stone slabs was erected on a threshold that preserved a negative impression of marble tiles. Traces of waterproof mortar could be seen. Fragments of tubuli survived (observed to a height of $0.36 \mathrm{~m}$ ) in some places by the south wall. A few marble tiles were found, coming most probably from the lower parts of the wall and floor, but the latter itself did not survive. Three pilae could be seen under a layer of loose sand in the center of the room.

Of the two baths the one by the west wall (No. 7a), excavated earlier by the American site presentation project, now underwent conservation. The bath occupied the full length of the west wall. Its bottom dimensions were $2.20 \mathrm{~m}$ by $0.73 \mathrm{~m}$, and it was about $1 \mathrm{~m}$ deep. Inside, by the east wall, there was a step $0.47 \mathrm{~m}$ high and $0.23 \mathrm{~m}$ wide. The inside walls were rendered with waterpoof mortar and plaster. The upper part of the bath was lined with bricks on every side, and additionally with stones on the north and south. Water was drained away from it through a hole running into a channel that proceeded along the courtyard.

The second bath (No. 7b), by the north wall, was situated on a higher level. It was lined with stones on the north 
and partly on the west, and bricks on the other sides. Marks in thick mortar on the south outer wall of the bath suggested decoration with marble tiles. The bottom dimensions of the bath were $1.81 / 1.72 \mathrm{~m}$ by $0.90 \mathrm{~m}$, and it was $0.86 \mathrm{~m}$ deep. By its south wall there was a step $0.35 \mathrm{~m}$ high and $0.23 \mathrm{~m}$ wide. It, too, was rendered with waterproof mortar and plastered. A lead pipe was fitted in an opening in the northwestern corner, discharging water to a channel running across room 10. Several fragments of windowpanes and pieces of pottery were discovered on the bottom.

In a later alteration, a small room (No. 7c), $1.43 \mathrm{~m}$ by $1.10 \mathrm{~m}$ in size, was set off by a divider wall. The fill of this cubicle consisted of rubble, as well as stones and pieces of bricks, overlying a layer of hard light yellow clay, 0.24$0.28 \mathrm{~cm}$ in thickness (observed in the south section), having ash and small rubble as its counterpart on the same level in the northern part. The rubble contained pieces of bricks and blackened ceramic pipes (flues with a diameter of $0.165-0.22 \mathrm{~m}$ ) [Fig. 7]. Ceramic tiles ( 0.44 $\mathrm{m}$ by $0.41 \mathrm{~m} ; 0.04 \mathrm{~m}$ thick), forming flues (tubuli, 0.03-0.07 m wide), were observed in the north wall. Four tiles at floor level were in good condition, another one could be seen above this level, and yet another one lay below the floor, adjacent to the wall. Judging by the preserved remains, the structure was at least $1.20 \mathrm{~m}$ high. Two ceramic floor slabs, $7 \mathrm{~cm}$ thick, survived fragmentarily in the northeastern corner. Below it a single pila was preserved by the north wall. Strongly blackened plaster survived to a height of $0.50 \mathrm{~m}$ on the walls of the room.

Room 10. A rectangular room ( $2.36 \mathrm{~m}$ by $1.90 \mathrm{~m})$ built of large stone blocks $(0.50 \mathrm{~m}$ by $0.40 \mathrm{~m} ; 0.20 \mathrm{~m}$ thick) save for the south wall, which

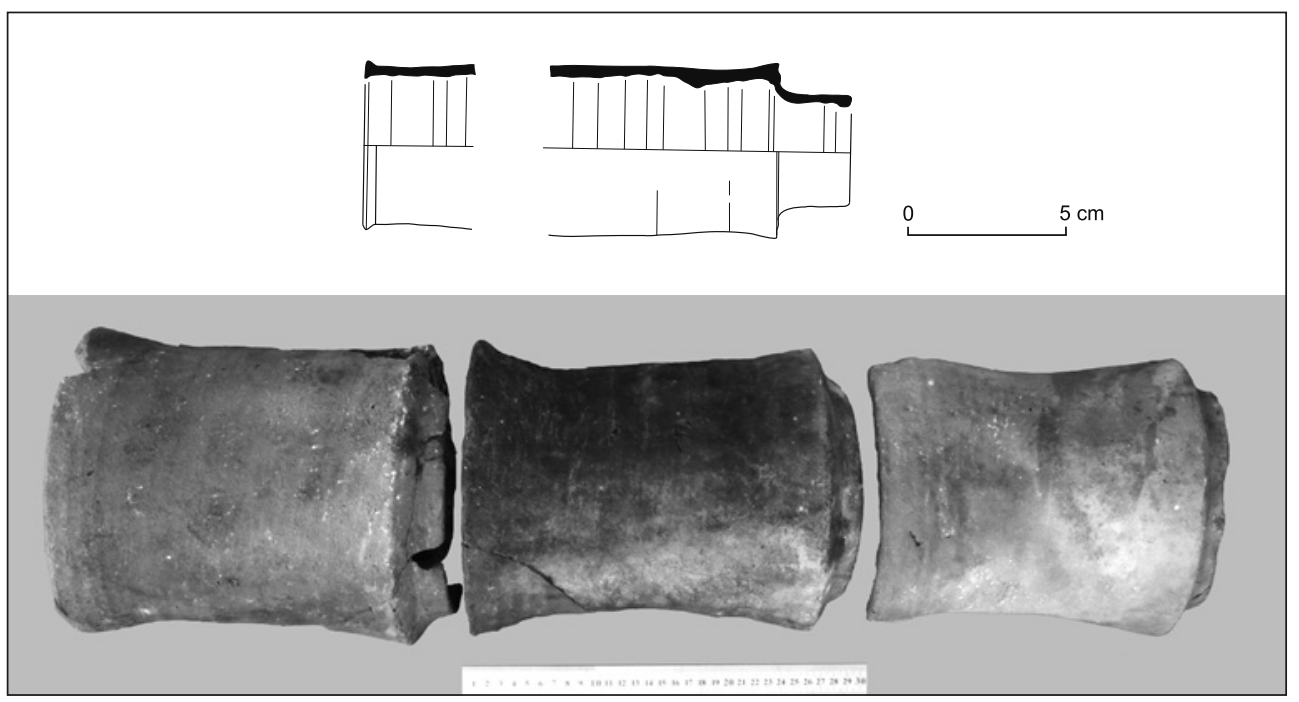

Fig. 7. Ceramic pipes

(Drawing G. Majcherek, W. Wojtowicz; photos R. Czerner) 
was constructed of thin slabs $(0.80 \mathrm{~m}$ by $0.36 \mathrm{~m} ; 0.10 \mathrm{~m})$. This difference resulted from a later alteration of the room, which was also when the only door leading to the caldarium was walled up. The walls survived to a height of $1.10 \mathrm{~m}$. The door opening in the east wall was $0.36 \mathrm{~m}$ wide. Loose sand in the top layers contained quantities of pottery. Stone blocks constituted the covering of a channel running along the south wall. The channel was $0.40 \mathrm{~m}$ by $0.10 \mathrm{~m}$ inside dimensions, the walls built of stone slabs on a level of bricks laid in a row on a substructure. The channel collected water from the northern bath, ran into the courtyard and turned south, collecting water also from the western bath. Traces of waterproof mortar survived on the walls of the room flush with the channel.

Pottery discovered on the level of the channel in the western part of the room was dated to the 2 nd-3rd century [Figs 10, 11]. Fragments of plaster painted yellow, pieces of windowpanes and lead strips also survived.

Rooms 8a and 18. Room 8a had been excavated partly in the 2011 season. Two marble columns had once separated room 8a from room 8b [Fig. 5]. The floor now was cleared for a section measuring $2 \mathrm{~m}$ south of the columns. A low course of marble revetment, $0.10 \mathrm{~m}$ high, was observed on the east wall. On a corresponding level on the west wall there was only a thick layer of mortar. A small hearth stood in the northeastern corner. A large iron hook, small potsherds, glass vessels and pieces of windowpanes, as well as animal bones were found in the fill on the floor.

The west wall in room $8 \mathrm{a}$ was very damaged at a point shared with rooms
$7 \mathrm{c}$ and 18 , and was in danger of collapse. A probe dug here demonstrated that part of the wall was built straight on sand without any foundation. Two parts of a stucco cornice were discovered in the rubble. Large stone blocks and marble tiles from the floor of room $8 \mathrm{a}$, as well as pieces of plaster painted black, were found in a deposit above the stairs leading to the cryptoportico (No. 18). A floor made of marble slabs with about $0.10 \mathrm{~m}$ of bedding underneath, laid over a substructure of small stones, was observed in the trench wall. About $0.40 \mathrm{~m}$ under the floor were pieces of bricks in situ stuck to the north wall. They originated from the vault of the cryptoportico leading to the praefurnium (see above, section on architectural research).

Room 11. A corridor $(6.03 \mathrm{~m}$ by $2.03 \mathrm{~m}$ ) running along room 5 and into the southern portico of courtyard 4 contained a fill of sand blanketing tumbled stone blocks (and a large iron nail), lying on rubble and compacted sand. The walls of the room were built of large stone blocks and survived to a height from $0.50 \mathrm{~m}$ to $0.97 \mathrm{~m}$. A door opening, $1.53 \mathrm{~m}$ wide, led east into room $8 \mathrm{~b}$. Three door openings were pierced in the south wall: the first from the east was $0.78 \mathrm{~m}$ wide, the next two $1 \mathrm{~m}$ wide.

A mosaic floor in this room [see Fig. 2] consisted of bands $0.45-0.60 \mathrm{~m}$ wide, made of large cubes of grey limestone $(3.0 \mathrm{~cm}$ to each side) along the north and south walls, surrounding a mosaic of marble tiles of different color and size in the center. A well opening, $0.46 \mathrm{~m}$ square in size, was found in the center with remnants of the original frame of four wooden beams and surrounded by larger marble tiles. 
The beams, $5 \mathrm{~cm}$ squared in section, were $0.65 \mathrm{~m}$ and $0.44 \mathrm{~m}$ long. Remains of a ceramic drainpipe could be traced in the mortar in the southeastern corner.

Room 13. A corridor was traced between chambers 12 and 14 found south of the courtyard. It was $1.08 \mathrm{~m}$ wide and was entered from the courtyard, through the southern portico. It gave on latrine 12 on the east side. The walls, preserved to a height of $0.80-0.90 \mathrm{~m}$, were painted. The decoration consisted of vertical bands separated by black lines $1 \mathrm{~cm}$ wide. The first band was grey with a claret pattern, imitating marbling, the second light green with a pink pattern, the third red. The uncovered edges of the painted plaster were protected. The corridor will be excavated once the supervision on site of a painting restorer can be ensured.

Room 12. The room was entered from the west side of corridor 13. Excavation started in 2012 was completed in 2013. Archaeological and architectural research as well as conservation work carried out in this chamber is reported on separately in this volume (see Koczorowska and Osiak 2015).

The shape was irregular: N-S, 3.86$3.31 \mathrm{~m}, \mathrm{E}-\mathrm{W}, 3.49-3.51 \mathrm{~m}$; the floor with small drain: $\mathrm{N}-\mathrm{S}, 2.80-2.66 \mathrm{~m}$, E-W, 2.02-1.89 m [Fig. 3]. The walls of the latrine were built of large stone blocks $(0.50 \mathrm{~m}$ by $0.42 \mathrm{~m}$ by $0.25 \mathrm{~m}$ ). The north wall was $3.77 \mathrm{~m}$ long and preserved to a height of about $0.62 \mathrm{~m}$; the west and east walls were $2.60 \mathrm{~m}$ high. A door in the east wall, $0.83 \mathrm{~m}$ wide $(0.77 \mathrm{~m}$ measuring with the mortar), led in from the corridor. Traces of white plaster have survived on the walls above the threshold $(0.28 \mathrm{~m}$ wide). Two column drums, $0.30 \mathrm{~m}$ in diameter and $0.17 \mathrm{~m}$ high, were found under a layer of sand and stone blocks tumbled from the walls.

Pottery from the fill of the room was dated to the 2 nd-3rd century; other finds included fragments of painted plaster (dark and light pink background with even darker thin pink lines) [Fig. 8]. A layer of packed soil (0.10-0.05 m) lay on the floor, covered by a layer of pure sand ( 0.40 to $0.15 \mathrm{~m}$ thick) under the collapse with small stones and pieces of mortar.

The fill of the drain contained large stone blocks as well as pieces of painted plaster (two larger ones were found by the west wall) and marble tiles of varying thicknesses coming from the walls, floor, small drain and seats. The tiles discovered were later used to reconstruct the latrine. A pseudo-Corinthian capital of the Marina type was discovered in the drain to the south, along with two drums (Dia. $0.30 \mathrm{~m}$ and $0.32 \mathrm{~m}, \mathrm{H} .0 .25 \mathrm{~m}$ and $0.35 \mathrm{~m}$ respectively) found in the northwestern corner. Below the deposit, about $0.20 \mathrm{~m}$ from the bottom of the drain, was a layer of compacted dark soil containing potsherds and animal bones. In the drain to the north, several pieces of glass pane were found.

The drain $(0.40 \mathrm{~m}$ to $0.49 \mathrm{~m}$ wide and $1.25-1.30 \mathrm{~m}$ deep, measuring from the level of the latrine floor) was traced on the north, south and west; on the east it ran under the floor, the covering at the level of about $0.40 \mathrm{~m}$ below the flooring (height $0.80 \mathrm{~m}$, width $0.40 \mathrm{~m}$ ). Sewage was removed through two openings in the north wall $(0.60 \mathrm{~m}$ high and $0.30 \mathrm{~m}$ wide) separated by a large stone forming a kind of barrier. The walls of the drain were rendered with waterproof mortar. Sockets in the east, north and south walls, 
Research and conservation in the Roman baths of Marina el-Alamein in the 2012 and 2013... EGYPT

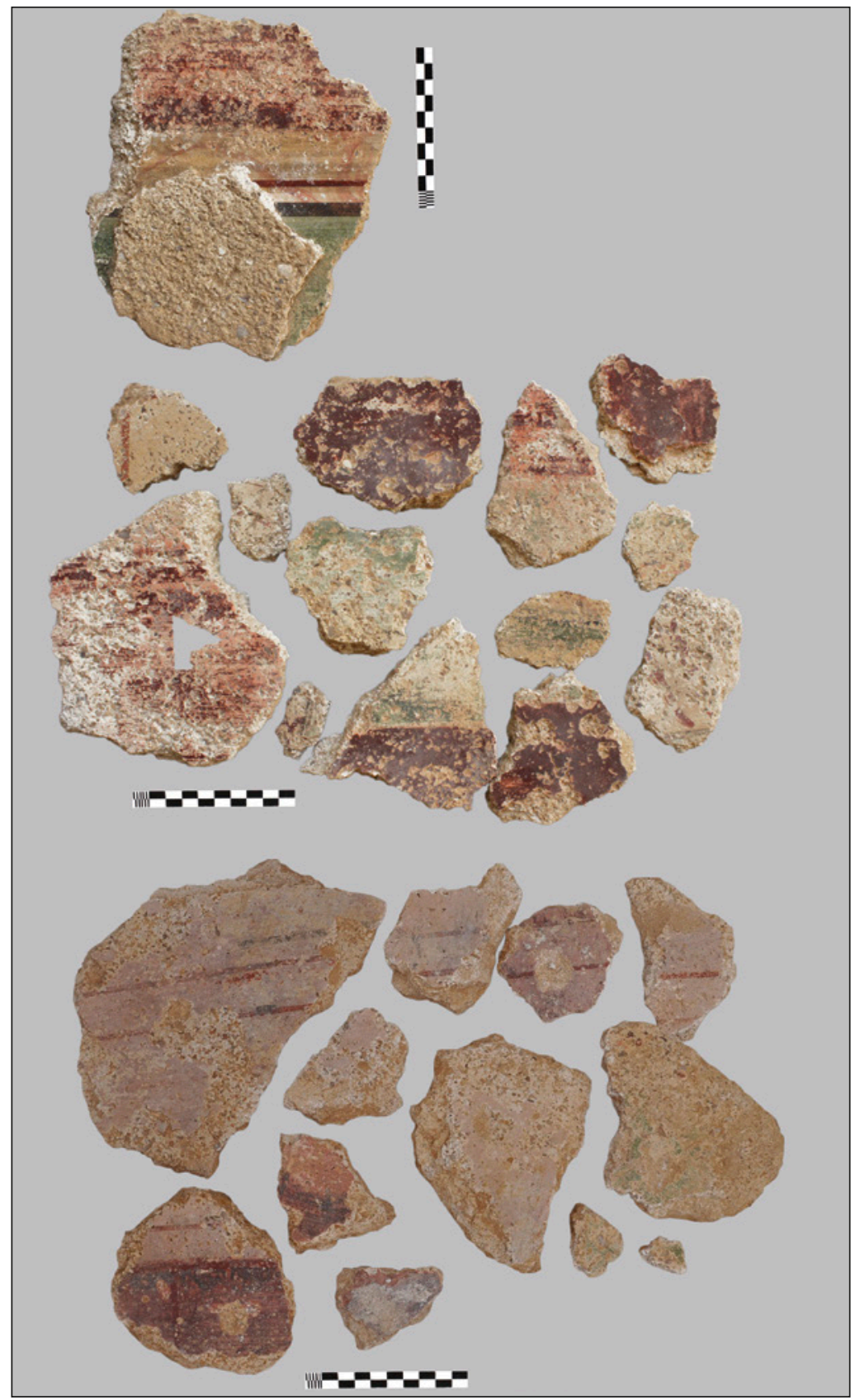

Fig. 8. Fragments of painted plaster

(Photos R. Czerner, W. Wójtowicz) 
$0.40 \mathrm{~m}$ by $0.12 \mathrm{~m}$ in size, located above the drain ( $1.63 \mathrm{~m}$ measuring from the bottom of the drain) were used to mount the seats.

A small gutter $(0.08 \mathrm{~m}$ deep, $0.12 \mathrm{~m}$ wide) ran around the inner space of the room on three sides; it was built of marble slabs of different length and thickness (measured from the outside: $0.035 \mathrm{~m}$, and from the inside: $0.02 \mathrm{~m}$ ). Its bottom was also laid with marble tiles.

The floor of the latrine was covered with marble slabs of various size. The largest were $1.26 \mathrm{~m}$ by $0.72 \mathrm{~m}$, the smaller ones measured $0.28 \mathrm{~m}$ by $0.45 \mathrm{~m}$. Long thin marble slabs $(0.46 \mathrm{~m}$ by $0.10 \mathrm{~m})$ in the southeastern part suggested repairs to the floor in this spot. Marble tile revetment was preserved fragmentarily on the lower parts of the east wall (up to a height of $0.24 \mathrm{~m}$ ). Above that the wall was painted (there were probably three layers of paint). Pieces of painted plaster found in the latrine documented wall decoration referring in design to the structural style [Fig. 8]. Plant motifs were also apparent in the assemblage.

Apart from the ceramics (examined by Dr. Grzegorz Majcherek, see below) and glass, as well as the architectural elements already described above, a small inscribed bronze ring was found; it had belonged to either a woman or a child.

Room 14 . The room was only partly excavated $(2.15 / 2.20 \mathrm{~m}$ by $3.53 \mathrm{~m})$. The door in the middle of the east wall was $0.93 \mathrm{~m}$ wide. Tumbled stone blocks lying under a layer of sand filled the chamber. A small structure of large stones $(1.30 \mathrm{~m}$ by $0.65 \mathrm{~m}, 0.30 \mathrm{~m}$ high) was discovered in the southwestern corner. The walls of the room were rendered with waterproof mortar.
Room 19. This was the interior of the civic basilica excavated by W.A. Da-szewski's team in 2005 (Daszewski 2007: 76-82), save for the southeastern corner, which was uncovered in 2013, providing an opportunity to carry out conservation work both in the basilica and in room 9 to the south. The fill consisted of tumbled stone blocks concealing underneath frag-mentary wall plaster painted cream and black, as well as pieces of marble tiles, animal bones and ceramics. The level immediately on the floor, about $5 \mathrm{~cm}$ thick, consisted of dark compacted soil with animal bones and ceramics. Burnt remains were also observed.

Ceramic water pipes [Fig. 7] were found in fragmentary condition, fixed to the wall with mortar in the south-eastern corner. They used to carry the water from the roof through a drain $(0.17 \mathrm{~m}$ wide, $0.15 \mathrm{~m}$ deep) into a cistern located below the floor in the southern part of the basilica. A well set in the southwestern corner of the room led to the cistern

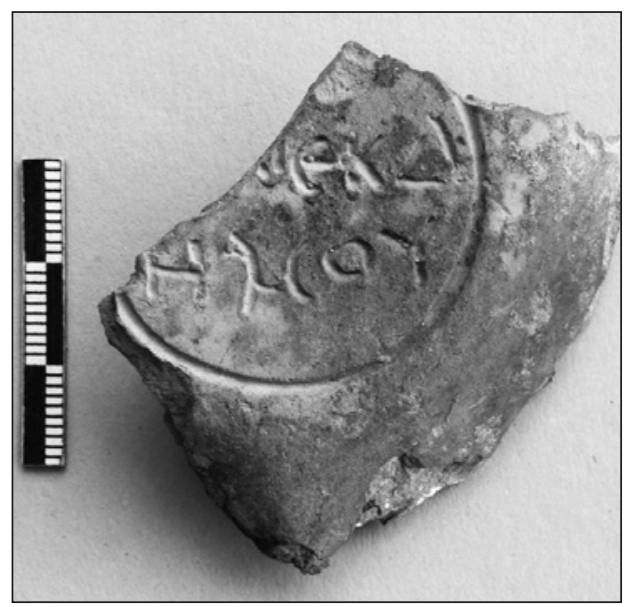

Fig. 9. Inscribed base of a clay lamp, inscription reading Synekdemou (Photo R. Czerner) 
(uncovered in 2005). Clearing of the west wall in this section of the basilica revealed an earlier passage to room $8 \mathrm{a}$; it had been walled up at some point.

A glass pawn was found among the stone blocks of the south wall during its reconstruction.

Room 9. A small room $(3.33 \mathrm{~m}$ by $3.20 \mathrm{~m}$ ) adjacent to the basilica on the south, leading from the street into the bath complex through a main entrance $(1.20 \mathrm{~m}$ wide) in the east wall. Steps probably led up to this door from the street level, similarly as in the basilica. The wide threshold was laid with fragmentarily preserved bricks $(0.25 \mathrm{~m}$ by $0.25 \mathrm{~m})$. Opposite, there was a door opening of the same width, leading to room $8 \mathrm{~b}$. The walls in the southeastern corner did not survive

The floor in the vestibule was covered with marble tiles of irregular size. A band $0.20 \mathrm{~m}$ wide by the north wall was paved with a mosaic of stone cubes. By the east wall, the floor surface was prominently sunken. Some white plaster survived up to a height of about $0.30 \mathrm{~m}$ above the floor in this part. Traces of black were noted (up to a height of $0.20 \mathrm{~m}$ ) on the lower parts of the north and south walls. Fragments of plaster painted red were preserved on the north wall (at a height of $0.25-$ $0.60 \mathrm{~m})$. A few rectangular sockets $(0.04 \mathrm{~m}$ by $0.05 \mathrm{~m}$ ) were documented in the walls at a height of $0.10-0.18 \mathrm{~m}$ above the floor.

Small pieces of plaster painted red, pottery and glassware, as well as a fragmentary inscribed base of a clay oil lamp were found clearing the layer on the floor [Fig. 9]. The inscription on the lamp is probably the name of the lamp producer: Synekdemou (Synekdemos means "travelling companion", A. Łajtar, personal communication).

\section{RECAPITULATION}

The work conducted at the site of the baths reveals an elegant complex of rooms with painted walls, marble facings and decorated stucco cornices. Floors were laid with big and small tiles of stone of different colors. Architectural elements represented chiefly capitals of columns and cornices.

The baths were built in the 2nd-3rd century $\mathrm{AD}$, but were reconstructed later. Apart from pieces of pottery and glassware, several fragments of glass panes, a few coins, bronze anchor bolts and fragments of iron ones, as well as bronze and iron nails were found.

[GB-C]

\section{NOTE ON THE POTTERY}

Pottery from the bath comes mostly from the fill, and cannot be safely attributed to any undisturbed contexts. Some of the finds may be either residual or post-dating the destruction of the building, therefore of limited chronological value. Although some architectural transformations and rebuilding are easily identified in the bath, so far none of the excavated deposits could be safely associated with these alterations. Only a few of the pottery finds originating from layers directly overlying the floor levels and latrine channel could actually be related to the functioning of the bath.

The range of the recorded pottery types is a representative cross-section of the early Roman repertoire, already identified both in the bathhouse and generally 
throughout the city. Most of the ceramic finds spanned a horizon in the 2nd-3rd/ early 4th century $\mathrm{AD}$ and cannot offer safe and detailed chronological conclusions. With a few exceptions, the bulk of the pottery represents heavily fragmented and featureless shards.

Common wares apparently prevailed in the collected material, although, apart from the water pipes, none of the identified vessels could be connected functionally directly with the bath. Beside some large bowls and basins [Fig. 10:1], occasional cooking pots, casseroles, and frying-pans were also recorded. While some of the common ware vessels were imported from the Nile Valley, as evidenced by their conspicuous dark red Nile alluvial fabric, others were in turn obviously manufactured in the Northwestern coastal region. Typical fabric of the latter, made of calcareous, slightly ferroneous clay, fired into various shades of red with a whitish surface, resulting from salt precipitation during drying, has been previously identified in workshops located throughout the Marmarica region (e.g., Tell Haraby, Majcherek and Shennawi 1992). The most frequent among them were globular cooking pots with slightly everted rim.

Of greater interest were several fragments of foreign cooking pots of orange, gritty fabric, most probably originating from the Aegean, as well as flat-bottomed frying pans with a tubular hollow handle in hard, gritty dark grey to red brick fabric, widely distributed in the Eastern Mediterranean (Riley 1979: 253-256).

As usual amphorae presented a more diversified picture. From the start of excavations in Marina, it was obvious that transport amphorae constituted over
$70-75 \%$ of recorded ceramic fragments, reflecting its role as a harbor town. The bulk of the amphorae sherds represented regional products, manufactured in the northwestern regions of Egypt. These were mostly the AE 3 class [Fig. 10:2] produced in workshops scattered above all on the southern coast of Mareotis Lake, and most likely destined as packaging for regionally produced white wine. Often referred to as "bitronconiques", these amphorae come in a variety of forms, differing mostly in rim or handle section, overall proportions and surface treatment, and are usually dated to the 2 nd-3rd century AD (Dixneuf 2011: 97-134). All the recorded fragments were made in calcareous marly clay typical of the Mareotic region. Some examples displayed a greenish fabric, an apparent sign of rather poor firing. The AE4 amphorae - yet another Mareotic variant of the common, Mediterranean Dressel 2-4 class - formed a more homogenous group, generally quite well attested at the site. Marmarican amphorae were represented again by fragments of bitronconical AE 3 vessels, produced on many sites in the region (Rieger and Möller 2011). On the other hand, their alluvial fabric counterparts imported from the Nile Valley, although less common, also made their presence felt.

All of the identified Egyptian amphorae were presumably used as wine containers. Flourishing wine production in the entire coastal region in the early Roman period and the potential role that the Marina harbor played in the commercial exchange of the region has been signalled already on several occasions. This phenomenon is perhaps best evidenced by a sizeable quantity of imported containers. Typically of Marina, 
the "pinched handle" amphorae (Agora G 199) formed the largest group of finds. As a matter of fact, they are exceptionally prolific both in the town area and in the cemeteries. Several fabric standards were identified, ranging from micaceous
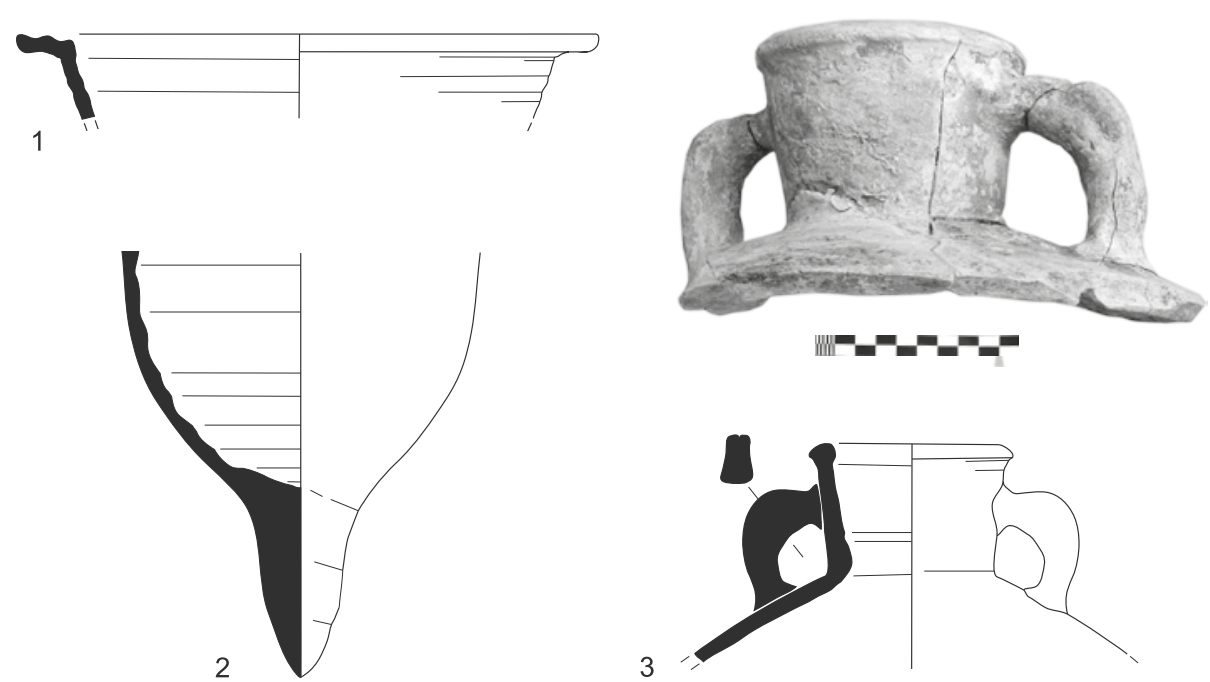

3
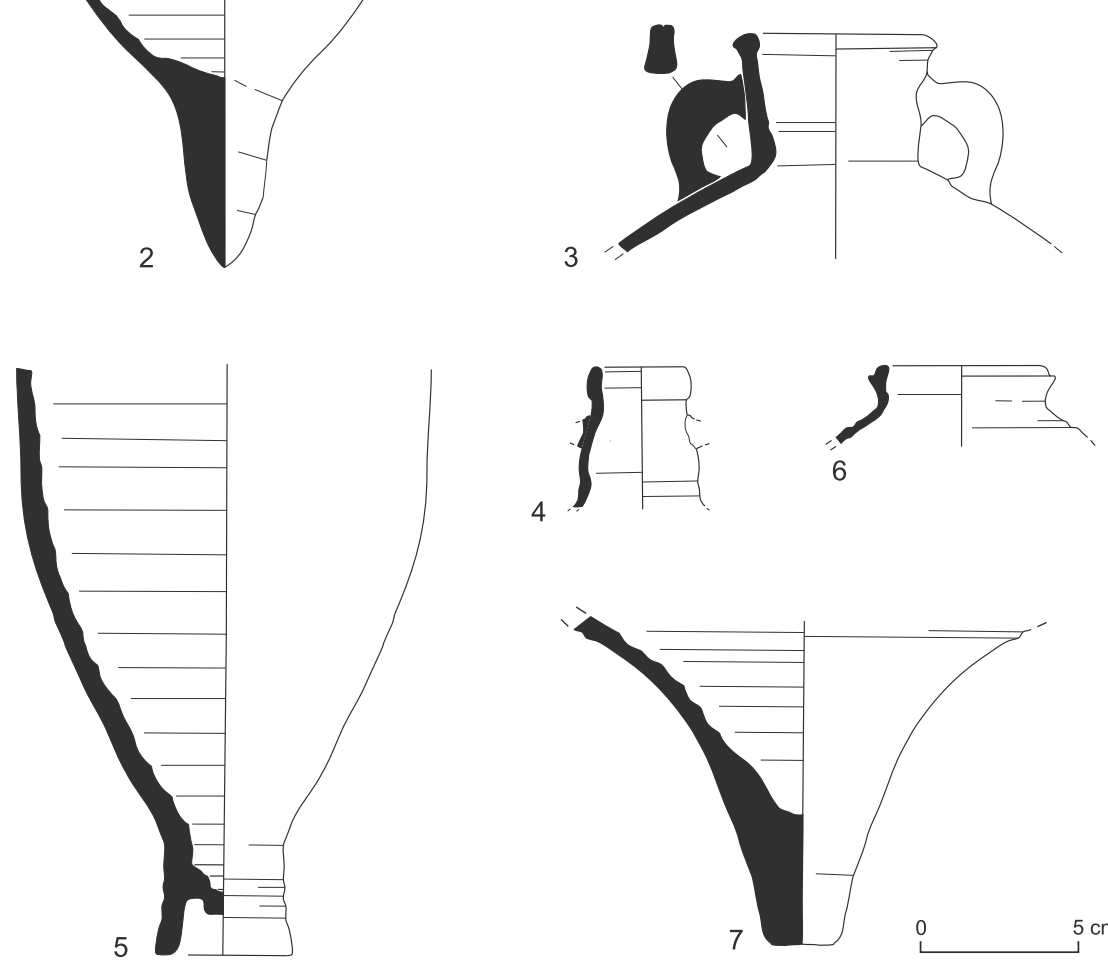

6

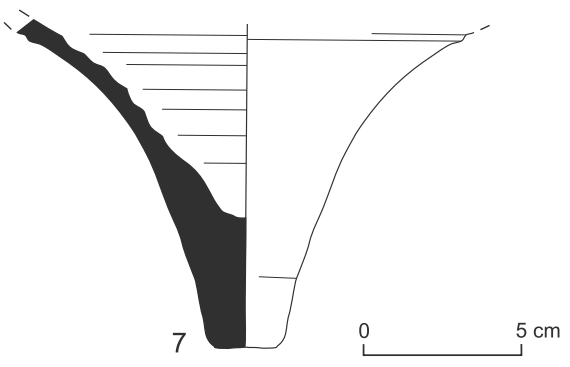

Fig. 10. Selection of coarse wares: 1 - basin; $2-A E 3$ amphora; 3 - amphora from a Cilician or Cypriote workshop; 4 - Cretan amphora (AC1); 5 - Kapitän II amphora; 6 - Benghazi Mid Roman Amphora 8; 7 - bottom part of amphora from latrine (No. 12)

(Drawing G. Majcherek, W. Wojtowicz; photo R. Czerner) 
orange-red to yellowish buff-beige, representing various Cilician and Cypriote workshops [Fig. 10:3]. Cretan amphorae (mostly $\mathrm{AC} 1, \mathrm{AC} 3$ and sporadically AC4) [Fig. 10:4], as well as some fragments of earlier versions of ubiquitous western Aegean LRA 3 amphorae, with a low tubular foot were also recognized. Fragments of ever-present Kapitän II amphorae [Fig. 10:5] and Cilician Pompei $\mathrm{V}$ class completed the repertory of salient Aegean types (Majcherek 2007). Quite surprisingly, a number of 3rd century AD Cirenaican amphorae (Benghazi Mid Roman Amphora 8) were also present in the assemblage [Fig. 11:6]. Apart from Marina and Alexandria, amphorae of this type were not recorded hitherto from Egypt. A single rim of African I amphora is the only example of containers imported from the western Mediterranean.
Cypriot Sigillata as usual occupied an unchallenged position among the fine wares, although the repertoire of recorded forms is rather limited. It included an almost complete example of a large bowl with an everted profiled rim (form P40) [Fig. 11:1], as well as fragments of a jug (P47). Shards of Egyptian imitations of the Cypriot Sigillata bowls (mostly forms P22 and P40) were quite numerous [Fig. 11:2], in stark contrast to the African Red Slip Ware represented by a few tiny fragments.

Several types of ceramic pipes were identified in the bathhouse. Larger, wider ones (Dia. maximum $22 \mathrm{~cm}$ ) were apparently used as flues, as attested by their smoke-blackened inner surface [see Fig. 7 bottom]. Another type of pipe, slender and thin walled (Dia. maximum $12 \mathrm{~cm}$, length approximately $30 \mathrm{~cm}$ ) similarly to those

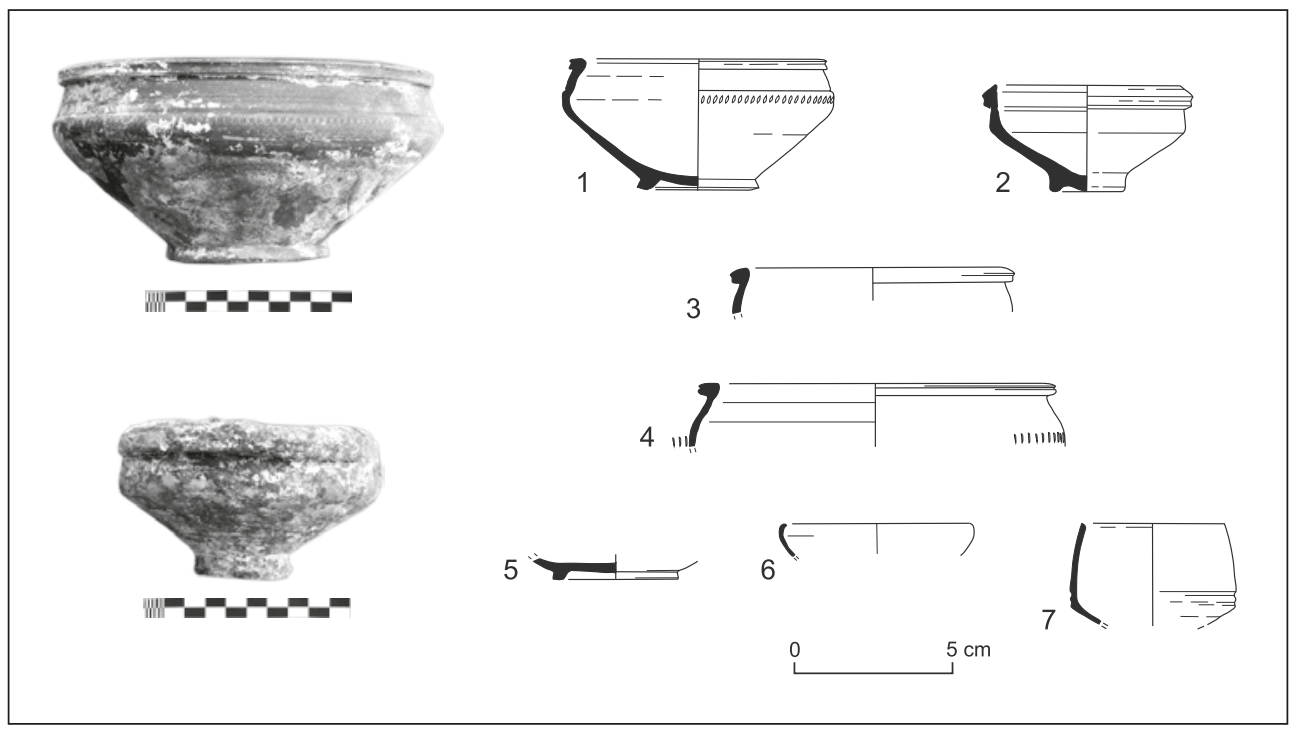

Fig. 11. 1 - P40 bowl; 2 - Egyptian imitation of P22 bowl; 3-4 - rims of P40 bowls; 5 - base of P11/12 bowl; 6 - P20 bowl; 7 - imported bowl a pareti sottili

(Drawing G. Majcherek, W. Wójtowicz; photos R. Czerner) 
mentioned earlier was also made in alluvial clay [see Fig. 7 top]. One fragmentarily preserved example was found still fixed to the wall in the southeastern corner of the building (room 19), apparently serving as a downpipe in the water-supply installation.

The latrine channel fill excavated in the 2013 season yielded a familiar range of forms, although no pot usually associated with toilets was observed. Moreover, contrary to typical latrine fill, no complete or nearly complete vessel was found. However, some of the examples recorded there may have had secondary usage as sanitary vessels (i.e., bottom part of the amphora [Fig. 10:7], or some kitchen pots). All the sherds originating from the channel were either heavily discolored or faeces-stained, both factors seriously impeding proper identification. Several fragments of Cypriot Sigillata rims and bases [Fig. 11:3-6] should be listed as much sought chronological markers.
They represent mostly variants of the ubiquitous $\mathrm{P} 40$ bowl dated to the first half of the 2 nd century $\mathrm{AD}$, and also other, slightly earlier forms (P11, P12 and P20). Some discoloured body fragments of Eastern Sigillata B and presumably of Çandarli ware were also recorded.

Excavations in house $\mathrm{H} 2$ a produced a similar, although more limited ceramic inventory. Some fragments of Cretan, Tripolitanian as well as Egyptian amphorae were found there. Of particular significance is a set of finds apparently related to one of the rebuilding phases of the house (found under the later pavement). It includes material mostly from the 2 nd-3rd century AD, although some finds of earlier date (1st-2nd century $\mathrm{AD})$ were also noted, namely tiny sherds of Cypriot Sigillata and fragments of imported bowls a pareti sottili [Fig. 11:7] These chronological premises, however, should be treated with due caution.

$[\mathrm{GM}]$

\section{CONSERVATION WORK IN THE SOUTHERN BATHS AND CIVIC BASILICA}

In the 2012 season, a full range of conservation work, including building conservation took place in rooms $4,7,8$ and 11 of the southern baths [Fig. 12].

In courtyard 4 the main focus was on the southern portico. The south wall of corridor 11, which is an extenson of the portico to the east, was built for the most part of its combined length of $13.52 \mathrm{~m}$ (except for a short eastern section) of slabs $0.55 \mathrm{~m}$ wide by $0.40-0.45 \mathrm{~m}$ high, and $0.27-0.28 \mathrm{~m}$ thick, laid vertically. Only one layer of blocks has survived. Some blocks had collapsed and others had eroded to such an extent that to restore the continuity of the wall and to protect it from further destruction it was necessary to replace them with different ones of the same size. Protective bands of mortar were placed on the edges of the preserved wall plaster and in the case of the polychrome plaster from corridor 13, additionally protected with provisional plywood covers. The eastern section of the wall, at the end of the corridor and east of the entrance to room 17, was made in a different technique, using thicker (i.e., $0.35 \mathrm{~m})$ and lower $(0.25-0.30 \mathrm{~m})$ blocks. An extra course of blocks had to be added in order to compensate for the difference 
in preserved height to the rest of the wall. It is now equal in height to the opposite north wall of corridor 11 , most of which was higher preserved and section of it had been rebuilt by the team already in 2011 .

An important surviving element of the joined rooms described, the southern portico of courtyard 4 and corridor 11 [see Fig. 2], is a mosaic floor of large tesserae. In 2009, the edges of the mosaic fragments preserved in the portico were protected and in some parts of it the mortar was filled in. After finishing the work in the current season, the whole mosaic was covered with geotextile and buried.
The most comprehensive work was carried out in 2012 in room 7 (caldarium) [see Fig. 4], this owing to the complicated layout and presence of various installations and facilities, such as two heated and one unheated bath plus elements of a heating system: relics of a hypocaust and of tubuli flues in the walls. The walls were consequently of different thickness, incorporating recesses, and the edges of the two bathing basins formed extra walls inside the room. Different materials were also used: stone blocks of varied size and ceramic bricks. Various mortars were also used. The layout of the interior was

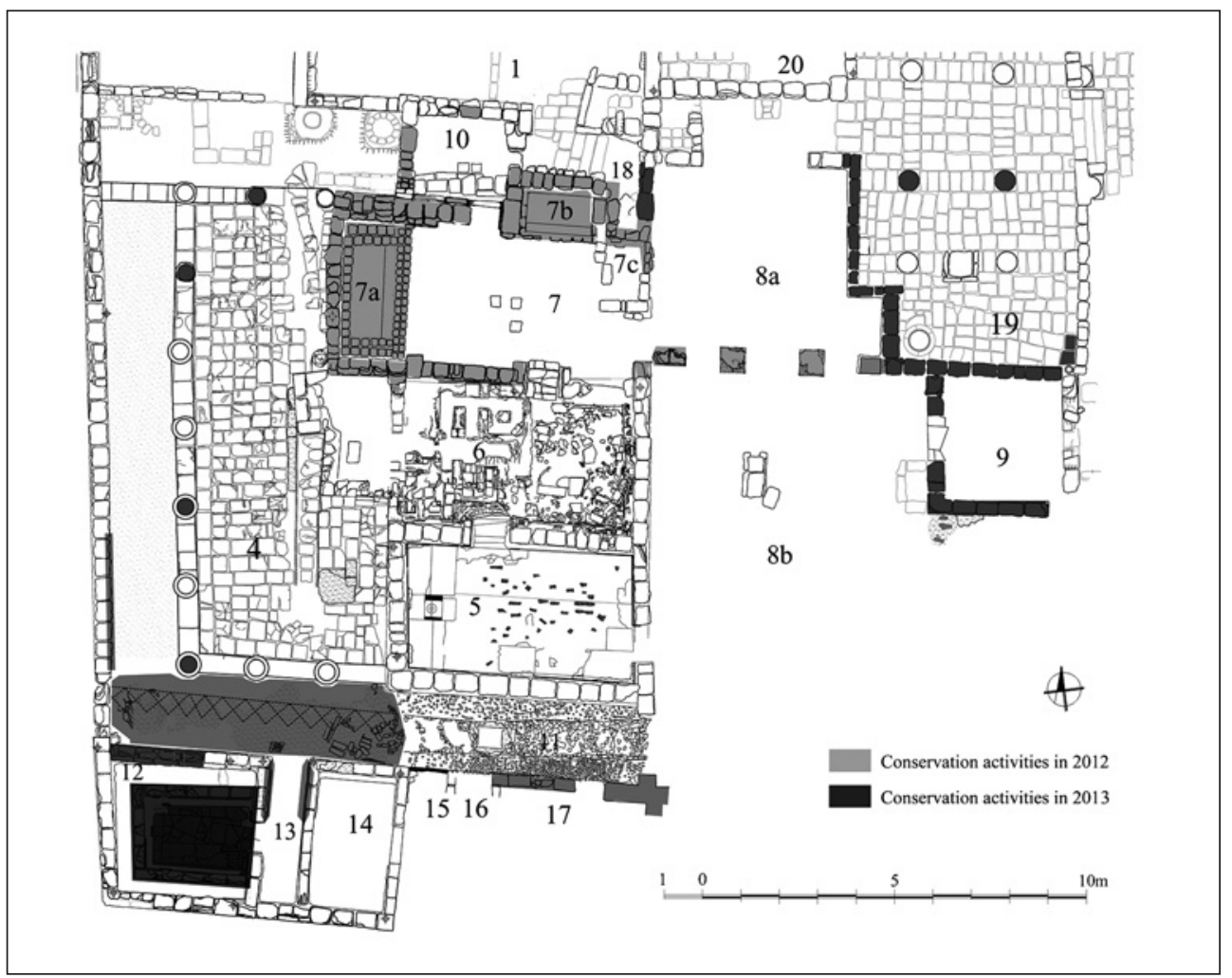

Fig. 12. Southern baths: areas of conservation activities in 2012 and 2013 shown in grey (Drawing A. Brzozowska, R. Czerner, A. Kubicka, K. Majdzik) 
additionally complicated by its alteration. As a result, conservation activities in the caldarium were diverse. Apart from the building work, conservation involved also small-scale, but often quite intricate activities.

The outer walls of the caldarium were in poor condition. Most of the limestone blocks it was built of were seriously and deeply eroded. The blocks from the northwestern and southwestern corners, that is, from the side of courtyard 4, were almost completely destroyed. Similarly, the blocks from the highest preserved layers were crumbling away. The filling in of joints in the facade had started in some sections in 2009 already, but for the wall as a whole it would not have been enough just to add another course of blocks to protect it. Sockets for the patches were cut in the eroded surfaces of blocks. The process concerned the outer facade of the part of the caldarium added later, that is the one to the west, housing alveus $7 \mathrm{a}$. It was restored from the west, north and south, and the damaged corners were also reconstructed. One or two layers of blocks were added on the top of the walls. Of course, it was impossible to replace all the blocks in the walls, hence the task was limited to only the most needy ones in the top courses of the south and north walls of the caldarium further to the east.

A consequence of the described conservation and partial reconstruction of the walls surrounding the western bath (7a) of the caldarium was the conservation of the relics of the bath itself. It was dictated both by the need to protect the remains from destruction and by display purposes. First of all, it was necessary to restore the walls of the basin built from brick. They have survived in reasonably good condition and almost to their full height, but their tops were crumbling. There was also a large breach in the side of the bath from the entrance (east). Reconstruction with original bricks recovered from the rubble reached different heights. These salvaged bricks were $24-25 \mathrm{~cm}$ squared and $3 \mathrm{~cm}$ thick. The mortar used for the reconstruction was similar to the original one, with filler of finely crushed bricks. In this way the shape of the bath was made more recognisable. Missing stretches of plaster in the bath and on its edges were not reconstructed, just the original parts were protected.

The second well-preserved bath (7b) in a recess in the north wall of the caldarium underwent the same process of conservation. It was located on a higher level and its front edge was more damaged. It was partly reconstructed and sections of the walls around the basin on the west, east and north were partly rebuilt. The upper two courses in the west wall were reconstructed. Blocks which had tumbled from the top preserved course of the wall in its northern and eastern section were restored, and the collapsed outer northeastern corner was rebuilt. Eroded surfaces of the blocks in the facade were also replaced with patches.

The conservation of the caldarium was completed with a thorough clearing of its interior, removing (after inventory) all of the collapsed blocks from its space and protecting the remains of a heating system.

Building and conservation work other than the protection of the northwestern corner proceeded in room 8 [see below and Fig. 5]. The east wall was partly protected by replacing damaged blocks and building over it. Two marble bases and 
a fragment of marble column shaft were put in place on preserved plinths situated in the passage between rooms $8 \mathrm{a}$ and $8 \mathrm{~b}$. The lower part of the shaft had been found inside the room in the 2011 season, but the provenance of the two bases could not be established with any measure of certainty. The bases had been moved to a nearby spoil heap when the site was first excavated, after some building work using heavy equipment carried out in 1985 . Their size, however, matched precisely the bottom diameter of the preserved fragment of the column shaft, and the plinth itself. The material was also similar, substantiating the decision to use them in this position for display purposes. To protect the bases from salt and humidity rising from the ground, their bottoms were separated from the foundation with a layer of bitumen paper.

In 2013, conservation work proceeded in rooms $4,8 \mathrm{a}, 9,12$ of the southern bath and room 19 of the basilica [see Fig. 12]. In courtyard 4 , the deteriorating shafts of columns were protected. Dilapidated areas were pointed. Some sections were also plastered. The southernmost two columns of the civic basilica were similarly protected.

The stub wall back of the caldarium (where the stairs to the cryptoportico were situated), separating it from the northwestern part of room $8 \mathrm{a}$ constituted a special conservation problem. The cryptoportico under the floor of room $8 \mathrm{a}$ had been constructed during an alter-ation of the building, hence the passage leading to it was installed later in the wall described. Thus, its upper sections lacked any support, and the surviving relic was in danger of collapse and had to be partly dismantled in 2012. The other parts were supported at the foundation level. Reconstruction began in the 2013 season. Above the passage, two reinforced concrete lintel beams $(0.09 \mathrm{~m}$ by $0.13 \mathrm{~m}$, $1.40 \mathrm{~m}$ long) were fixed parallel to one another. Appropriate grooves were cut in the underside of the stone blocks that lay on them and the blocks were then fixed in place. Further courses of the wall will be reconstructed on this solid base, reconstructing the original appearance of a completely unsupported wall hanging above the passage (which originally used to be there), but ensuring solid support in the form of a hidden lintel.

The shared wall between room $8 \mathrm{a}$ and the civic basilica in its southern part continued to be protected in 2013. Damaged blocks were replaced and new courses were added on the wall top. A new course of stone blocks was also added on top of the remaining part of the basilica wall in its northern section to protect the heavily eroded surface A pilaster adjacent to the wall was also reconstructed with two layers of blocks on top. Likewise, one or two layers of stone blocks were added on top of standing walls in rooms 9 and 19 , that is, in the southern part of the basilica and a neighboring room. The wall separating the two interiors and the wall between rooms 9 and $8 \mathrm{~b}$ with a door frame in it were similarly extended upwards and protected [see Fig. 6]. Damaged and eroded parts were replaced with good quality blocks of the same size.

The most interesting room in the bath complex of those which underwent conservation in 2013 was room 12 housing the latrine [see Fig. 3]. Having survived in exceptionally good condition, the rich decor of the interior, comprising marble floor and revetment at plinth level, as well 
as a small marble gutter in front of the seats, was especially qualified for display. Protection and partial reconstructionanastylosis were essential and were accomplished using the detached pieces salvaged from the fill during excavation. The north wall was built of uright slabs, $0.55 \mathrm{~m}$ wide by $0.40-0.45 \mathrm{~m}$ high, and
$0.27-0.28 \mathrm{~m}$ thick. Only one course of such blocks has survived. The four westernmost blocks were eroded to such a degree that to restore the continuity of the wall and to protect it from further destruction, it was necessary to replace them with different ones of the same size.

$[\mathrm{RC}]$

\section{Prof. Rafał Czerner}

Wrocław University of Technology, Faculty of Architecture

50-317 Wrocław, Poland, ul. Bolesława Prusa 53/55

rafal.czerner@pwr.edu.pl

Dr. Grażyna Bąkowska-Czerner

Jagiellonian University, Center for Comparative Studies of Civilizations

31-044 Kraków, Poland, ul. Grodzka 52

grazyna.bakowska-czerner@uj.edu.pl

Dr. Grzegorz Majcherek

Polish Centre of Mediterranean Archaeology, University of Warsaw

00-497 Warsaw, Poland, ul. Nowy Świat 4

g.majcherek@uw.edu.pl

\section{REFERENCES}

Daszewski, W. A. (1995). Témoignage de l'urbanisation de la côte méditerranéenne de l'Égypte à l'époque hellénistique et romaine à la lumière des fouilles de Marina el-Alamein. BSFE, 132, 11-29.

Daszewski, W. A. in collaboration with I. Zych, G. Bąkowska and A. Błaszczyk (2007). Marina el-Alamein. Excavation report, 2005. PAM, 17, 75-97.

Dixneuf, D. (2011). Amphores égyptiennes: production, typologie, contenu et diffusion, III siècle avant J.-C-IXe siècle après J.-C. [=Études Alexandrines 22]. Alexandria: Centre d'études alexandrines.

Koczorowska, M., and Osiak, W. (2015). Selected conservation work in Marina el-Alamein in the 2012 and 2013 seasons. PAM, 24/1, 101-111.

Krencker, D., Krüger, E., Lehmann, H., and Wachtler, H. (1929). Die Trierer Kaiserthermen I. Ausgrabungsbericht und grundsätzliche Untersuchungen römischer Thermen $[=$ Trierer Grabungen und Forschungen 1/1]. Augsburg: Filser.

Majcherek, G. (2007). Aegean and Asia Minor amphorae from Marina el-Alamein. In S. Marchand and A. Marangou (Eds.), Amphores d'Égypte de la Basse Époque à l'époque arabe I [=CCE 8/1] (pp. 9-31). Cairo: Institut français d'archéologie orientale.

Majcherek, G., and Shennawi, A. (1992). Research on amphorae production on the northwestern coast of Egypt. CCE, 3, 123-136. 
Medeksza, S., Czerner, R., and Bąkowska-Czerner, G. with contributions by I. Fuks-Rembisz, W. Grzegorek, G. Majcherek, M. Mrozek-Wysocka, and P. Zambrzycki (2012). Marina el-Alamein. Conservation work in the 2009 season. PAM, 21, 79-105.

Medeksza, S., Czerner, R., Bąkowska, G., Grzegorek, W., Kucharczyk, R., Lis, J., and Zambrzycki, P. (2011). Marina el-Alamein. Polish-Egyptian Restoration Mission: Conservation work in 2008. PAM, 20, 103-128.

Nielsen, I. (1990). Thermae et balnea: The architecture and cultural history of Roman public baths I. Text. Aarhus: Aarhus University Press.

Rieger, A.-K., and Möller, H. (2011). Kilns, commodities and consumers: Greco-Roman pottery production in Eastern Marmarica (Northwestern Egypt). AA, 2011(1), 141-170.

Riley, J. A. (1979). The coarse pottery from Benghazi. In J. A. Lloyd (Ed.), Excavations at Sidi Khrebish, Benghazi (Berenice) II. Economic life at Berenice [=Libya Antiqua Supplements 5] (pp. 91-467). Tripoli: Department of Antiquities, People's Socialist Libyan Arab Jamahirya. 